\title{
The components of career capital and how they are acquired by knowledge workers across different industries
}

\author{
M. Sutherland*, G. Naidu, S. Seabela, S. Crosson and E. Nyembe \\ Gordon Institute of Business Science, University of Pretoria, Pretoria 0001, Republic of South Africa \\ *To whom all correspondence should be addressed \\ sutherlandm@gibs.co.za
}

\begin{abstract}
The literature shows that the way in which knowledge workers manage their careers in the global economy has changed fundamentally in the last twenty years. Career capital is a tradable commodity between and within organisations which impacts both human resource managers and knowledge workers. There is insufficient empirical evidence of the components of career capital and how these are acquired and there has been a dearth of investigation as to whether career capital is managed differently in different industries. The research was conducted in two phases. The first qualitative phase via 21 in-depth interviews identified 27 components of career capital and 23 methods of career capital accrual. In phase two quantitative data was collected, using those constructs, from 200 knowledge workers in four sectors: the public service sector and in manufacturing, financial and high tech research and development industries. The research determined the most important career capital components and methods of their accrual and showed these to differ greatly between the four employment sectors. The data raises questions with regard to two important themes in the career literature.
\end{abstract}

\section{Introduction}

The impact of globalisation and wide ranging technological advancements has driven new forms of organisation, new ways of working and managing careers. Knowledge workers can no longer rely on acquiring the traditional requirements for a job at the outset of their careers. Instead they need to constantly acquire relevant competencies for their careers to ensure they are continually employable and successful career capitalists. It has become paramount for knowledge workers and human resource professionals to get empirical evidence (De Vos \& Dries, 2013; Clarke, 2013) to understand the career capital components that are required to ensure career success and how these components are acquired throughout a knowledge worker's career journey.

The concept of career capital was proposed by Defillippi and Arthur (1994) and is viewed as the value created through ongoing improvement in career position and recognition in the competitive external labour market (inter-organisational recruitment) as well as the internal labour market (intraorganisational staffing). Aligned to this is the concept of the boundaryless career, described in the seminal work of Arthur and Rousseau (1996) where knowledge workers strive to develop their skills, capabilities and competencies to accumulate career capital that may be traded within or between organisations. Career development gains new meaning in the context of the employability demands in the knowledge economy (Kuijpers \& Scheerens, 2006) and there is heightened importance for the knowledge worker to focus on building relevant and recognizable career capital (Baruch, 2006). As much as organisations are no longer fully responsible for developing individuals' careers (Clarke, 2013) human resource managers need to understand the career capital components that are attractive in the skills market and ensure that the organisation's attraction, retention, succession and development plans meet these needs. For most individuals their career is a substantial part of their life in terms of energy and time invested alongside skills and relationships built in order to manage their careers (Clarke \& Patrickson, 2008). The purpose of this study is to firstly extend the understanding of components of career capital as discussed by Lamb and Sutherland (2010) and the methods used to build career capital. Secondly, based on the notion of tradable and boundaryless careers, the research aims to ascertain the key career components that are deemed common or different across four employment sectors (Heilmann, 2011).

\section{Literature review}

The knowledge economy makes a habit of introducing new ways of working, triggering changing career arrangements around the globe (Arthur, 2008). Increased mobility (Perotti, Wall \& McLaughlin, 2010) fast-changing work environments, increased self -interest and a greater level of career support from employers are seen as characteristics of the modern career (Kuijpers \& Scheerens, 2006). Previously, career realities were characterized as being linear and static, representing among others, assured employability, regular promotions, predictable job moves with organizations taking responsibility for managing individuals (Herriot, 1998). Increasingly however, individuals are enacting careers outside organizational boundaries; defining career success on their own terms rather than by the organizational measures of salary and rank; decoupling individual careers from organizations; putting more emphasis on individuals to take responsibility for their own career development (Baugh \& Sullivan, 2005). The notion of protean careers is one in which the individual, rather than the organisation, takes 
responsibility for transforming their career path (Donnelly, 2009).

An organisation's competitive advantage is dependent on the organisation's intellectual capital (Mrinalini \& Nath, 2008; Tai \& Chen, 2009) and the knowledge-based economy is not one of diminishing but rather increasing returns (Arthur \& Rosseau, 1996; Lamb and Sutherland, 2010). Bourdieu (1986) explores this economic system with knowledge being a concept that is created through investment and has the ability to be traded. Harris (2001) describes the process of obtaining knowledge as taking on the characteristics of an investment activity that increases the capacity to generate additional capital. Knowledge within a particular career field accumulates with time and experience, this contributes to an individual's tradable capital in that field. Intangibles assets such as skills, professional knowledge, organizational capabilities, reputational capital and networks are imperative for success and hold value for both the organisation and the individual (Edvinsson, 2002).

\section{The components of knowledge workers' career capital}

The seminal work of Bourdieu (1986) defines capital as a mix of the three types of capital; Economic capital such as income, Social capital such as relationships, social networks and class membership that has the potential to be converted into economic capital and Cultural capital or competence that is academically sanctioned by a recognised institution (Mayrhofer, Meyer, Iellatchitch \& Schiffinger, 2004) such as an individual's educational qualifications. A body of research has confirmed that career capital comprises of three dimensions of knowing (Suutari \& Mäkelä, 2007; Dickmann \& Harris, 2005; Inkson \& Arthur, 2001) originally defined by DeFillippi and Arthur (1994) as knowing whom, knowing why and knowing how. Knowing whom consists of social relations within and external to the organisation and within a professional network that is relevant to the career (DeFillippi \& Arthur, 1994). Knowing how represents work related skills, knowledge and competencies (DeFillippi \& Arthur, 1994; Dickmann \& Harris, 2005). Knowing why relates to the individual's identity, career related choices and the motivation and energy the individual brings to their careers (DeFillippi \& Arthur, 1994; Inkson \& Arthur, 2001). Jones and DeFillippi (1996) added knowing what, involving understanding industry dynamics; knowing when, an understanding of the best timing of roles, activities and choices and knowing where, understanding where to enter the industry, where to train to remain within the industry of choice and where to advance through identification and exploitation of relevant opportunities. Lamb and Sutherland (2010) added to these concepts the need for emotional maturity and intelligence as knowing-oneself. They illustrated two different groupings of career capital; "must have" capital and "nice to have" capital, which are career differentials that add marginal value to successful knowledge worker careers. All these forms of career capital create an opportunity for knowledge employees to trade their skill within organisations or when transferring to other organisations or industries (Burfitt \& Ferrari, 2008).

Movement capital encompasses the individual skills, knowledge, competencies, and attitudes influencing an individual's career mobility opportunities, which in turn influences their likelihood of career success (Forrier, Sels \& Steynen, 2009). Forrier et al. (2009) identified the following dimensions of movement capital: Human capital encompassing knowledge, skills, and abilities. As Fugate, Kinicki and Ashforth (2004) frame it human capital represents an individual's ability to meet the performance expectations of a given occupation. Social capital which Forrier et al. (2009) find should focus on external ties and not so much on the collectivity (network) itself and its internal structure. Self-awareness - this relates to the question who am I and who do I want to be? Fugate et al. (2004) refer to this as career identity, or an 'internal career compass' providing direction (McArdle, Waters, Briscoe \& Hall, 2007). Adaptability refers to the willingness and ability to change behaviours, feelings and thoughts in response to environmental demands (McArdle et al., 2007). Adaptability allows people to evolve and enables and motivates them to adapt their human capital, social capital, and career identity to new circumstances (Forrier et al., 2009).

The notions of career capital (Inkson \& Arthur, 2001) and organizational knowledge capital potentially integrate individual and organizational interests, based on the latency of such capital as a key resource in which both individuals and organizations can invest, and from which both can generate added value. Employees invest in career capital and have aspiration for a future return - a dividend (in the form of pay, status, recognition and responsibility) received on the capital invested, and/or the growth of that capital in the form of renewed identity or motivation (knowing-why), new skills or knowledge (knowing-how), and extended networks (knowing-whom) (Inkson \& King, 2011). According to Boxall (2007) a firm's economic objectives are to ensure that its approaches to managing and developing people (among other resources) are cost-effective and deliver a return on investment. Over the long term, and particularly in high value-added sectors their objectives extend to building competitive advantage through high-quality knowledge resources in the form of employees. Despite the writings above there appears to be little empirical evidence on the relative value of the components of career capital.

\section{Accumulation of career capital}

The boundaryless career drives career capitalistic (Inkson \& Arthur, 2001) behaviour in which employees need to continuously learn and update their knowledge and skills to grow their career capital (Burke \& $\mathrm{Ng}, 2006$ ). However as Clarke (2013) hypothesises the organizational career is not over. Hence for both the individual knowledge worker and the human resource professional there is need for evidence on how career capital is acquired. Baruch and Hall (2004) describe a change in the traditional single lifelong career cycle to multiple shorter learning cycles. Lazarova and Taylor 
(2009) state that career capital is amassed through selecting and participating in activities that allow the accumulation of diverse knowledge, extensive professional networks and maintain high visibility. Sullivan and Baruch (2009) state that individuals reshape and repackage their knowledge, skills and abilities to maintain employability. De Vos and Dries (2013) Clarke (2013) Lamb and Sutherland (2010) Verbruggen, Sels and Forrier (2007) and Arthur and Rosseau (1996) mention a wide range of techniques to develop ones career capital including; continual learning from experience and application of the learning into a new business context; making an effort to understand the political environment or the dynamics of the playing field within the organisation; making a concerted effort to build a social network and visibility within the industry; continual challenging complacency by establishing a personal vision and establishing stretch goals, task enrichment, movement between jobs, validation agents, career counselling and workshops, mentoring, succession planning, training, outplacement, external network development etc. Participation in these activities can be initiated by the individual (career self-management) or others (e.g organizational career management) (Forrier et al., 2009; Clarke, 2013).

Career capital typically grows through transfer, experience and exposure as knowledge workers move through and across organisations accumulating experiences (Lamb \& Sutherland, 2010). This does not abdicate the organisation of its responsibilities. Mallon and Walton (2005) find that although individuals believe that they are responsible for their own learning and career development they are uncertain how to acquire the learning. This highlights the importance of organisational signals as mechanisms to guide knowledge workers toward appropriate learning. Improved career management by a company can positively impact on a knowledge worker's job satisfaction resulting in the improved retention of key knowledge workers (Chen, Chang, $\&$ Yeh, 2003). However there is a dearth of evidence in the literature as to how knowledge workers accumulate their career capital and how this is best supported by organizational human resource practices.

\section{Career capital: Differences across industries}

Trevor (2001) asserts that on a continuum of usefulness, 'movement capital' is seen as a highly tradable and transferable asset of the knowledge worker in the globalized world. Forrier et al. (2009) developed a model mapping how individual and structural factors may concurrently influence an individual's mobility opportunities and work-role transitions and it illustrates that if career capital is specific to an industry it limits a knowledge worker's movement capital across industries. There are indications that knowledge workers should be segmented rather than seen as a homogenous grouping (Sutherland \& Jordaan, 2004). The Centre for International Labour Market Studies (2011) found that the overriding challenge facing industries are the differing labour markets. This suggests that the type of skills and experience required may vary considerably between sectors. Heilmann (2011) found some similarities and some differences in how a small sample of managers in the ICT and paper manufacturing sectors managed their careers. Human resource managers and career capitalists need to know how industry specific career management is. However there is almost no data in the literature illustrating the differences or similarities between career management practices across different employment sectors. In this study samples were obtained from the manufacturing, financial, and high tech research and development (R\&D) fields as well as the public service in South Africa.

\section{The research questions}

Research question 1: What is the relative importance of the components of career capital?

Research question 2: What is the relative usage of the methods of accrual of the components of career capital?

Research question 3: Is the importance of the career capital components different for the public service, banking, manufacturing and high-technology R\&D industries?

Research question 4: Are the methods of acquiring career capital components different in the public service, banking, manufacturing and high-technology research and development industries?

\section{Research methodology}

The study comprised of two phases. The first phase verified and extended Lamb and Sutherland's (2010) model through a qualitative study using in-depth interviews to develop and validate the constructs for phase two. Phase two was a quantitative survey to determine the relative importance of the components of and methods for development of career capital across four employment sectors.

Phase 1. The population was defined as knowledge workers, line managers and human resource professionals in the banking, high tech R\&D and public service sectors in South Africa. Judgemental non-probability sampling (Zikmund, 2003) was used to identify individuals who could contribute to the understanding of the research problem. Data was collected through 21 in-depth face to face interviews that were guided by a standardised interview schedule using open ended questions. The interviews began with the researcher introducing the concept of career capital. The interviewees were then asked to identify the components of career capital and their methods used to acquire them. The common themes in this qualitative primary data were determined through content analysis (Miles \& Huberman, 1994). The coding revealed career capital components that were more defined than the abstract constructs identified during the literature review. By combining the output from the 21 interviews and the literature review, 27 career capital components and 23 methods of their accumulation were identified. The constructs are shown in Tables 2 and 3 below. 
Phase 2. This phase took the form of a quantitative descriptive study implemented through a survey using selfadministered questionnaires (Zikmund, 2003). The introductory section gave a brief description of career capital to ensure that the respondents had a standardized understanding of the concept. A 5 point Likert scale was used to gather the data. For research question 1, the ' 1 ' rating indicated that the component was 'not important at all' and the ' 5 ' indicated it was 'critically important'. For research question 2 , the ' 1 ' rating indicated that the method of accrual was 'not used at all' and the ' 5 ' indicated it was 'used extensively'. The questionnaire was pretested on 20 knowledge workers in face to face settings to enable the researchers to detect and rectify problems with the questionnaire design (Zikmund, 2003). There was occasionally no unique manner to express the idea behind a construct in a single term. Thus potentially ambiguous constructs were defined by using multiple terms to define the construct. The population for phase 2 was defined as high performance knowledge workers within the high tech R\&D, finance, manufacturing and public service sectors. Nonprobability quota (Zikmund, 2003) sampling was used. The data was collected in single large multinational organisations within each of the three business sectors but across a number of public service sector divisions. The data was collected by means of self-administered questionnaires distributed by both hand delivery and electronically via email. The sample is shown in Table 1 below. ANOVAs using an alpha level of 0.05 as the cut-off point were used to test between sector differences.

\section{Research limitations}

The generalizability of the findings is limited by three of the sub-samples having being collected in single organisations within the industries. Self-report surveys have as an inherent bias the possibility of normative answers being given.

Table 1: The sample for the quantitative study

\begin{tabular}{l|l}
\hline Number of Respondents & Industry \\
\hline 56 & High tech R\&D \\
\hline 48 & Manufacturing \\
\hline 55 & Financial services \\
\hline 41 & Public sector \\
\hline
\end{tabular}

\section{Results}

\section{Research question 1: The relative importance of the components of career capital}

Table 2 shows the relative value of the 27 career capital components across the total sample, rank ordered by the sum of scores.
Table 2: Ranking of importance of career capital components

\begin{tabular}{|c|c|c|c|}
\hline Rank & Career Capital Component & Sum & Median \\
\hline 1 & Self-motivation and drive & 856 & 5.00 \\
\hline 2 & Determination and perseverance & 816 & 5.00 \\
\hline 3 & $\begin{array}{l}\text { Being known for delivery and } \\
\text { execution }\end{array}$ & 810 & 5.00 \\
\hline 4 & $\begin{array}{l}\text { Ability to participate in a team } \\
\text { (team player) }\end{array}$ & 810 & 5.00 \\
\hline 5 & $\begin{array}{l}\text { Flexibility and adaptability; ability } \\
\text { to adapt to various environments }\end{array}$ & 802 & 4.00 \\
\hline 6 & $\begin{array}{l}\text { People skills; having good working } \\
\text { relationships }\end{array}$ & 789 & 4.00 \\
\hline 7 & Ability to influence/motivate & 775 & 4.00 \\
\hline 8 & $\begin{array}{l}\text { Knowing yourself or emotional } \\
\text { Intelligence. }\end{array}$ & 768 & 4.00 \\
\hline 9 & $\begin{array}{l}\text { A comprehensive technical } \\
\text { understanding. (to know why) }\end{array}$ & 765 & 4.00 \\
\hline 10 & $\begin{array}{l}\text { Passion for the industry } \\
\text { environment }\end{array}$ & 763 & 4.00 \\
\hline 11 & Ability to lead a team (team leader) & 757 & 4.00 \\
\hline 12 & $\begin{array}{l}\text { Industry acumen; understanding of } \\
\text { the bigger picture }\end{array}$ & 756 & 4.00 \\
\hline 13 & Personal reputation & 744 & 4.00 \\
\hline 14 & Educational qualifications & 741 & 4.00 \\
\hline 15 & Action orientation & 738 & 4.00 \\
\hline 16 & $\begin{array}{l}\text { Understanding your reactions and } \\
\text { feelings to different situations }\end{array}$ & 736 & 4.00 \\
\hline 17 & $\begin{array}{l}\text { Understanding challenges of } \\
\text { managing in your industry and } \\
\text { working environment }\end{array}$ & 729 & 4.00 \\
\hline 18 & Relevant hands on knowledge & 723 & 4.00 \\
\hline 19 & $\begin{array}{l}\text { Multi-disciplinary experience i.e. } \\
\text { experience in diverse disciplines } \\
\text { e.g. different roles in the } \\
\text { organisation }\end{array}$ & 716 & 4.00 \\
\hline 20 & Technical ability (To know how) & 709 & 4.00 \\
\hline 21 & $\begin{array}{l}\text { Knowledge and understanding of } \\
\text { entire product life cycle or a system } \\
\text { view }\end{array}$ & 708 & 4.00 \\
\hline 22 & $\begin{array}{l}\text { A practical or pragmatic } \\
\text { understanding of the technical and } \\
\text { working environment }\end{array}$ & 706 & 4.00 \\
\hline 23 & Networking within the organisation & 691 & 4.00 \\
\hline 24 & Experience in industry & 672 & 4.00 \\
\hline 25 & $\begin{array}{l}\text { Networking with stakeholders like } \\
\text { customers and suppliers. }\end{array}$ & 651 & 4.00 \\
\hline 26 & $\begin{array}{l}\text { Ability to identify new opportunities } \\
\text { for the organisation }\end{array}$ & 642 & 4.00 \\
\hline 27 & Networking outside the company & 636 & 4.00 \\
\hline
\end{tabular}

The ratings of the empirical evidence of the relative importance of the components of career capital show that five themes are apparent in the top half of the table. These may be considered the factors which differentiate successful career capitalists from less successful ones.

Firstly, the top two career capital components are the achievement orientation personal characteristics of selfmotivation and drive, rated first by a wide margin, and determination and perseverance (2). Aligned to this is the emotional intelligence of knowing oneself (8). All these concepts involve an internal locus of control. Martin and 
Marshall (1995) found that from an awareness of personal needs, self-determined individuals choose goals and doggedly pursue them. Suutari and Smale (2008) emphasise that knowing-why career capital consists of an overall selfawareness about what is necessary in order to master one's career. Such self-understanding establishes the confidence and motivation needed to pursue a desired career-path (Cappellen \& Janssens, 2005; Inkson \& Arthur, 2001). In addition this involves an individual's capability to make the right career choices and look for the right kind of development paths across jobs and employers (Suutari \& Smale, 2008). Self-awareness is an 'internal career compass' providing direction (McArdle et al., 2007).

The second important grouping of the components of career capital is the importance of having influential interpersonal relationships; being a team player (4), having people skills and good working relationships (6), the ability to influence and motivate (7) and the ability to lead a team (11). This component refers to the knowing-whom component of career capital. Ballout (2007) found that having good working relationships is particularly important to ensure a reciprocal flow of information between knowledge workers and thus the development of multiple networks of relationships fosters ease of knowledge transfer. Lamb and Sutherland (2010) emphasise the need to be able to give direction as a source of differentiation.

The third important aspect of career capital is having a good reputation (13) in particular being known for delivery and execution (3) as this boosts confidence and gives an indication of the knowledge workers ability to perform and deliver in the future. Inkson and Arthur (2001) said that the competencies knowledge workers generate from experience as they progress moves with the individual and becomes integrated into the texture of the next role.

The fourth theme of career capital is flexibility and adaptability including being adaptable to different environments (5). Ballout (2007) noted that the motivation to tolerate change and ambiguity and personal identification of opportunities for new learnings are integral aspects career development. Lamb and Sutherland (2010) emphasise the importance of contextual adaptability.

The fifth most important component of career capital is having comprehensive industry relevant technical understanding (9), including having a passion for the industry (10) and industry acumen (12). Inkson and Arthur (2001) in their definition of knowing-how career capital included the skills, expertise, and tacit and explicit workrelated knowledge needed to carry out the job successfully within the chosen context. Haslberger and Brewster (2009) support this saying that the knowing-why capabilities are seen as fundamental for commitment, which in turn improves performance. Increasing a person's career capital is thus beneficial for the individual, the organisation and the industry (Clarke, 2013).

\section{Research question 2: The relative usage of methods of accruing career capital}

Table 3 shows the relative usage of methods for accruing career capital across the total sample.

Table 3: Ranking of usage of methods for the accrual of career capital

\begin{tabular}{|c|c|c|c|}
\hline Rank & $\begin{array}{l}\text { Method of Acquiring Career } \\
\text { Capital }\end{array}$ & Sum & Median \\
\hline 1 & Willingness to learn & 854 & 5 \\
\hline 2 & $\begin{array}{l}\text { Ensuring that you deliver on your } \\
\text { promise }\end{array}$ & 827 & 5 \\
\hline 3 & Further training and development & 739 & 4 \\
\hline 4 & $\begin{array}{l}\text { Association with and learning } \\
\text { from successful individuals inside } \\
\text { the organisation }\end{array}$ & 738 & 4 \\
\hline 5 & $\begin{array}{l}\text { Networking and relationship } \\
\text { building internal to the company }\end{array}$ & 732 & 4 \\
\hline 6 & Innovation in the way you work & 730 & 4 \\
\hline 7 & $\begin{array}{l}\text { Eagerness to adopt new ways of } \\
\text { working }\end{array}$ & 715 & 4 \\
\hline 8 & $\begin{array}{l}\text { Developing a complete } \\
\text { competence in your role before } \\
\text { seeking new opportunities }\end{array}$ & 696 & 4 \\
\hline 9 & $\begin{array}{l}\text { Ensuring multi-disciplinary } \\
\text { exposure }\end{array}$ & 692 & 4 \\
\hline 10 & $\begin{array}{l}\text { Having a personal vision and } \\
\text { development plan }\end{array}$ & 692 & 4 \\
\hline 11 & $\begin{array}{l}\text { Adding value by challenging the } \\
\text { status quo }\end{array}$ & 687 & 4 \\
\hline 12 & $\begin{array}{l}\text { Reading to keep updated with } \\
\text { current industry events and issues }\end{array}$ & 686 & 4 \\
\hline 13 & $\begin{array}{l}\text { Keeping to the rules of my } \\
\text { organisation }\end{array}$ & 655 & 4 \\
\hline 14 & $\begin{array}{l}\text { Improving education } \\
\text { qualifications }\end{array}$ & 627 & 4 \\
\hline 15 & Being mentored or coached & 621 & 3 \\
\hline 16 & $\begin{array}{l}\text { Identification of opportunities to } \\
\text { improve visibility and reputation } \\
\text { at higher levels in the } \\
\text { organisation }\end{array}$ & 607 & 3 \\
\hline 17 & $\begin{array}{l}\text { Depending on my original } \\
\text { qualification }\end{array}$ & 598 & 3 \\
\hline 18 & $\begin{array}{l}\text { Networking and relationship } \\
\text { building with stakeholders like } \\
\text { suppliers and customers }\end{array}$ & 587 & 3 \\
\hline 19 & $\begin{array}{l}\text { Association with and learning } \\
\text { from successful individuals } \\
\text { outside the organisation }\end{array}$ & 572 & 3 \\
\hline 20 & $\begin{array}{l}\text { Changing jobs within current } \\
\text { company }\end{array}$ & 561 & 3 \\
\hline 21 & Attending conferences & 518 & 3 \\
\hline 22 & $\begin{array}{l}\text { Networking and relationship } \\
\text { building external to the company }\end{array}$ & 494 & 3 \\
\hline 23 & $\begin{array}{l}\text { Changing jobs within current } \\
\text { industry }\end{array}$ & 448 & 2 \\
\hline 24 & $\begin{array}{l}\text { Luck has played a role in your } \\
\text { career }\end{array}$ & 417 & 2 \\
\hline 25 & Presenting at conferences & 407 & 2 \\
\hline 26 & Changing jobs across industries & 361 & 1 \\
\hline
\end{tabular}


The table provides empirical evidence of the wide disparity in the methods used to develop one's career capital. The ten most highly used techniques can be combined into four themes.

Firstly, the most important approach to developing one's career is a commitment to change. This is enacted via a willingness to learn, ranked (1), which is essential to one acquiring further training and development (3) the outcomes of which needs to be both innovation in the way you work (6) and willingness to change the way you work (7) and all this being underpinned by having a personal development plan (10). Many of these are aligned to the knowing-why component of career capital (Inkson \& Arthur, 2001) Burke and Ng (2006), Baruch and Hall (2004) and Banai and Wes (2004) showed the need for career capitalists to self-organise to gain training and development. While Suutari and Makela (2007) affirm that knowledge workers seek employment that enables them to gain and use new skills. The findings also support Fugate and Ashforth (2003) who state that career identity provides a representation of "who I am" and "who I want to be" at work. This theme shows the need for training and development to have the outcome of changed work behaviour which is one of the measures of the return on investment of training.

The second theme is a new finding to the literature regarding the high value placed on internal networking, having associations and building good relationships with successful individuals within the organisation (4\&5). This supports the work of DeFillippi and Arthur (1994) and Adler and Kwon (2002) on the knowing-whom career capital component of career-relevant networks, but it narrows the conception down to contacts within one's organisation. This is at odds with much of the literature such as Forrier et al. (2009) who emphasise the need to focus on external ties.

A third theme is reputational i.e. being known for delivering on your promises (2), and developing a core competence before moving onto the next job (8). These reflect the importance of building credibility and a strong track record as the bedrock for a sustainable career rather than a track record of rapid mobility which occurs in labour markets with an undersupply of high value talent. This is aligned to the knowing-how construct. Suutari and Makela (2007) affirm that the knowledge worker realises their personal vision by having different work experiences and by developing knowing-why, knowing-how and knowing-whom career capital, thus as a result, developing their own career identities. Lamb and Sutherland (2010) illustrate the self-reinforcing cycle of building on experience. While Clarke (2013) shows the importance of lateral career moves within an organisation in order to build bench strength for a successful career.

The fourth theme is the value of getting multi-disciplinary exposure (9). This illustrates that in combination with the third theme one needs to ensure both breadth and depth in expanding one's competencies. This was further supported by
Baruch (2004) in that the intelligent career places a great deal of emphasis on individual competencies and role behaviours, and the connections between these competencies (application of the different forms of knowing) and organisational employment processes and practices. Clarke (2013) and Inkson and King (2011) show how the employee and organisation need to work together to build solid careers to the mutual benefit of both parties.

The ten lowest ranked items show a few dominant themes as to what is not used as a means to develop a successful career. The big surprise in the data is the rejection of building a career externally. Firstly, networking with a range of external stakeholders is rated poorly (18, 19 \& 22). Secondly, changing jobs between companies and between industries is not being used to build a career (23 \& 26). The findings contradict DeFillippi and Arthur (1994) and others who assert that the new world of work encourages knowledge worker mobility across organisational boundaries to build career capital. These two themes indicate that the idea of the boundaryless career and the high importance of mobility in successful career management may be overstated in the literature and supports the assertion of Clarke (2013) that the organizational career is not dead, and that much of one's development happens within an organisation. The second theme alters the concept of career social capital to being to a large extent internal to the firm (Parker \& Arthur, 2000). Attending and presenting at conferences offers little value for career development (21 and 25). The last theme that is rejected as a way of developing one's career is by having an external locus of control in two forms: depending on one's original qualification (17), which is taken as a given to start ones career, and depending on luck (24).

The evidence from 200 knowledge workers as to what is and what is not used to build successful careers has important implications for both the knowledge worker and the human resource profession. These findings need a wider audience to alert knowledge workers to the dangers of non-evidence based career advice.

\section{Research question 3: Differences across industries in importance of career capital components}

The table below indicates the results of the ANOVAs to test for differences between the 4 industries ranked according to the p-values obtained. The acronyms used are as follows: FFinance, M-Manufacturing, P-Public Sector and RResearch and Development. The mean values for each item per sector are shown. The asterisks indicate the items for which the null hypothesis is accepted at $\mathrm{p}$ of 0.05 i.e. there is no difference across the 4 sectors for these items. The numbers in the ranking column indicate the item ranking as in Tables 2 and 3 above. 
Table 4: Comparison of rankings of career capital components across the 4 sectors

\begin{tabular}{|c|c|c|c|c|c|c|}
\hline \multirow{2}{*}{ Career Capital Components } & \multirow{2}{*}{$\begin{array}{l}\text { Ranking in } \\
\text { Table } 2\end{array}$} & \multirow{2}{*}{ p-value } & \multicolumn{4}{|c|}{ Mean } \\
\hline & & & $\mathbf{F}$ & M & $\mathbf{P}$ & $\mathbf{R}$ \\
\hline Educational qualifications & 14 & $0.991 *$ & 3.97 & 3.94 & 4.00 & 3.96 \\
\hline Determination and perseverance & 2 & $0.435^{*}$ & 4.43 & 4.22 & 4.29 & 4.42 \\
\hline Action orientation & 15 & $0.420^{*}$ & 4.03 & 3.90 & 4.10 & 3.81 \\
\hline Self-motivation and drive & 1 & $0.068^{*}$ & 4.74 & 4.45 & 4.59 & 4.48 \\
\hline $\begin{array}{l}\text { A practical or pragmatic understanding of the } \\
\text { technical and working environment }\end{array}$ & 22 & 0.046 & 3.96 & 3.88 & 3.88 & 4.25 \\
\hline $\begin{array}{l}\text { Knowledge and understanding of the entire product } \\
\text { life cycle or a system view }\end{array}$ & 21 & 0.035 & 4.05 & 3.53 & 3.93 & 3.65 \\
\hline A comprehensive technical understanding. & 9 & 0.034 & 3.93 & 4.12 & 4.00 & 4.38 \\
\hline People skills; having good working relationships & 6 & 0.031 & 4.48 & 4.14 & 4.12 & 4.13 \\
\hline Being known for delivery and execution & 3 & 0.004 & 4.59 & 4.37 & 4.39 & 4.06 \\
\hline $\begin{array}{l}\text { Flexibility and adaptability; ability to adapt to } \\
\text { various environments }\end{array}$ & 5 & 0.000 & 4.71 & 4.16 & 4.32 & 3.92 \\
\hline $\begin{array}{l}\text { Industry acumen; understanding of the bigger } \\
\text { picture }\end{array}$ & 12 & 0.000 & 4.64 & 3.96 & 4.39 & 3.19 \\
\hline Technical ability (to know how) & 20 & 0.000 & 3.96 & 3.94 & 3.71 & 4.42 \\
\hline Relevant hands on knowledge & 18 & 0.000 & 3.47 & 4.20 & 4.00 & 3.85 \\
\hline Experience in industry & 24 & 0.000 & 4.05 & 3.59 & 3.20 & 3.44 \\
\hline $\begin{array}{l}\text { Ability to identify new opportunities for the } \\
\text { organisation }\end{array}$ & 26 & 0.000 & 3.83 & 3.61 & 3.34 & 2.88 \\
\hline Personal reputation & 13 & 0.000 & 4.53 & 4.04 & 4.24 & 3.73 \\
\hline $\begin{array}{l}\text { Multi-disciplinary experience i.e. experience in } \\
\text { diverse disciplines e.g. different roles in the } \\
\text { organisation }\end{array}$ & 19 & 0.000 & 4.64 & 3.37 & 3.66 & 3.40 \\
\hline Networking within the organisations & 23 & 0.000 & 4.16 & 3.69 & 3.34 & 3.44 \\
\hline $\begin{array}{l}\text { Networking with stakeholders like customers and } \\
\text { suppliers. }\end{array}$ & 25 & 0.000 & 4.14 & 3.53 & 3.27 & 2.90 \\
\hline Networking outside the company & 27 & 0.000 & 4.10 & 3.14 & 3.59 & 2.73 \\
\hline Passion for the industry environment & 10 & 0.000 & 4.67 & 3.82 & 3.63 & 3.90 \\
\hline Ability to participate in a team (team player) & 4 & 0.000 & 4.86 & 4.33 & 4.15 & 4.13 \\
\hline Ability to lead a team (team leader) & 11 & 0.000 & 4.34 & 4.06 & 4.29 & 3.46 \\
\hline Ability to influence/motivate & 7 & 0.000 & 4.55 & 4.14 & 4.17 & 3.73 \\
\hline Knowing yourself or emotional Intelligence. & 8 & 0.000 & 4.60 & 4.14 & 3.88 & 3.75 \\
\hline $\begin{array}{l}\text { Understanding your reactions and feelings to } \\
\text { different situations }\end{array}$ & 16 & 0.000 & 4.47 & 3.96 & 3.66 & 3.46 \\
\hline $\begin{array}{l}\text { Understanding challenges of managing in your } \\
\text { industry and working environment }\end{array}$ & 17 & 0.000 & 4.21 & 4.04 & 4.10 & 3.33 \\
\hline
\end{tabular}

The table shows that of the 27 variables analysed only four career capital components were ranked the same across the four sectors, indicating that the components of career capital are very different across the four industries sampled. This has wide ranging implications for both human resource professionals and knowledge workers. It is of interest that there were no differences across the 4 sectors for the overall two top ranked career capital components; self-motivation and drive and perseverance and determination. Both items occurred in the top five means of all 4 sectors. An inspection of the top five and bottom five means per each sector shows the R\&D sector to differ significantly in that the three technical component questions fell in the top five while the interpersonal components were rated as being of much less importance. The public sector is the only one in which understanding the bigger picture, flexibility and adaptability were rated as most important. In manufacturing delivery and execution plus hands on knowledge were seen as critically important which makes intuitive sense given the measurable outcomes of the industry. In the finance sector a breadth of understanding was seen as critical with passion for industry, industry acumen and multidisciplinary exposure being highly valued. These findings call into question the concept of the boundaryless career which has been viewed as a given in the literature for nearly two decades and sides more with the work of Clarke (2013). It also suggests that movement between industries is not common and needs competency reskilling. Career values and anchors are known to play a role in the selection of one's industry of choice (Hall et al., 2008). There thus needs to be segmentation of career management advice that differs between industries. This has implications for human resource managers, tertiary institutes and career consultants.

\section{Research question 4: Differences across the 4 sectors in methods of accruing career capital}

The results for this research question were obtained by performing ANOVA on the 26 variables across the four industries. The same method is used as for Table 5 . 
Table 6: Comparison of methods of acquiring career capital across the 4 sectors

\begin{tabular}{|c|c|c|c|c|c|c|}
\hline \multirow[t]{2}{*}{ Methods of Accrual } & \multirow{2}{*}{$\begin{array}{l}\text { Ranking in } \\
\text { Table } 3\end{array}$} & \multirow[t]{2}{*}{ p-value } & \multicolumn{4}{|c|}{ Average } \\
\hline & & & $\mathbf{F}$ & M & $\mathbf{P}$ & $\mathbf{R}$ \\
\hline $\begin{array}{l}\text { Association with and learning from successful } \\
\text { individuals inside the organisation }\end{array}$ & 4 & $0.557 *$ & 3.97 & 4.10 & 3.90 & 3.88 \\
\hline Depending on my original qualification & 17 & $0.376^{*}$ & 3.09 & 3.12 & 3.44 & 3.13 \\
\hline Willingness to learn & 1 & $0.345^{*}$ & 4.69 & 4.49 & 4.59 & 4.58 \\
\hline $\begin{array}{l}\text { Developing a complete competence in your role before } \\
\text { seeking new opportunities }\end{array}$ & 8 & $0.247 *$ & 3.90 & 3.80 & 3.61 & 3.54 \\
\hline Innovation in the way you work & 6 & $0.113^{*}$ & 4.17 & 3.80 & 3.78 & 3.90 \\
\hline Further training and development & 3 & $0.085^{*}$ & 4.16 & 4.16 & 3.80 & 3.79 \\
\hline Ensuring multi-disciplinary exposure & 9 & $0.066^{*}$ & 4.02 & 3.59 & 3.54 & 3.63 \\
\hline Changing jobs across industries & 23 & 0.027 & 2.31 & 1.78 & 1.80 & 1.75 \\
\hline $\begin{array}{l}\text { Reading to keep updated with current industry events } \\
\text { and issues }\end{array}$ & 12 & 0.016 & 4.03 & 3.35 & 3.59 & 3.58 \\
\hline $\begin{array}{l}\text { Networking and relationship building internal to the } \\
\text { company }\end{array}$ & 5 & 0.014 & 4.26 & 3.82 & 3.76 & 3.79 \\
\hline Adding value by challenging the status quo & 11 & 0.012 & 3.98 & 3.41 & 3.56 & 3.63 \\
\hline Ensuring that you deliver on your promise & 2 & 0.009 & 4.69 & 4.18 & 4.44 & 4.40 \\
\hline Being mentored or coached & 15 & 0.004 & 3.72 & 3.57 & 3.02 & 2.96 \\
\hline Keeping to the rules of my organisation & 13 & 0.002 & 3.81 & 3.78 & 3.27 & 3.21 \\
\hline $\begin{array}{l}\text { Association with and learning from successful } \\
\text { individuals outside the organisation }\end{array}$ & 19 & 0.002 & 3.57 & 3.16 & 2.73 & 2.75 \\
\hline Luck has played a role in your career & 24 & 0.001 & 2.74 & 2.00 & 2.02 & 1.94 \\
\hline Changing jobs within your current industry & 26 & 0.000 & 3.05 & 2.45 & 1.95 & 1.92 \\
\hline Changing jobs within your current company & 20 & 0.000 & 3.78 & 3.06 & 2.44 & 2.52 \\
\hline Improving education qualifications & 14 & 0.000 & 3.95 & 3.47 & 2.98 & 2.88 \\
\hline $\begin{array}{l}\text { Identification of opportunities to improve visibility and } \\
\text { reputation at higher levels in the organisation }\end{array}$ & 16 & 0.000 & 3.93 & 3.39 & 2.83 & 2.81 \\
\hline Eagerness to adopt new ways of working & 7 & 0.000 & 4.28 & 3.82 & 3.49 & 3.54 \\
\hline $\begin{array}{l}\text { Networking and relationship building with } \\
\text { stakeholders like suppliers and customers }\end{array}$ & 18 & 0.000 & 3.97 & 3.00 & 2.66 & 2.71 \\
\hline $\begin{array}{l}\text { Networking and relationship building external to the } \\
\text { company }\end{array}$ & 22 & 0.000 & 3.45 & 2.33 & 2.27 & 2.35 \\
\hline Having a personal vision and development plan & 10 & 0.000 & 4.16 & 4.08 & 3.29 & 3.27 \\
\hline Attending conferences & 21 & 0.000 & 3.36 & 2.57 & 2.49 & 2.48 \\
\hline Presenting at conferences & 25 & 0.000 & 2.78 & 2.20 & 1.85 & 1.87 \\
\hline
\end{tabular}

Out of 26 variables analysed across the four industries only seven methods of acquiring career capital were found to be rated the same. Again there are profound industry differences. This needs to be taken cognizance of by knowledge workers, human resource managers and industry associations. In looking at the top 5 means for each sector all included the top 2 items in table 3 plus networking with successful individuals within the organization. The differences in the remaining top two items were that in finance there is greater emphasis on networking and eagerness to adapt ways of working reflecting the rapid rate of change of product and service offerings in the financial sector. In the other three sectors further development and training were greatly used. In manufacturing have a personal development plan was highly valued (this may be due to sampling bias as this global organization places great value on PDPs) with much less emphasis placed on innovation (which is probably due to the standardization of processes globally). The public sector ratings were the most closely reflective of the findings in table 3. Again we see from the ANOVAs that one size does not fit all when it comes to mechanisms used to develop ones career. This supports the ideas of Sullivan and Baruch (2009) Lamb and Sutherland (2010) and Forrier et al. (2009).

\section{Conclusion}

The concept of career capital points to the challenge for both the knowledge worker and the human resource professionals to focus on building relevant and recognisable career capital for the benefit of both the employee and the organisation to ensure career mobility for high talent employees. This study gives empirical findings as to the relative value of the constructs which contributes to this field of knowledge. The finding of large differences between industry sectors is of particular interest.

The research findings revealed that human resource professionals need to ensure that their training and development activities are both wide ranging and industry specific. In particular they need to encourage productive networking within the organisation to facilitate both career development and knowledge acquisition and sharing. HR practitioners need to find innovative ways to gather information from their knowledge workers as to how they can facilitate their career development within the organisation (Clarke, 2013). They also need to make explicit to knowledge workers that both parties must take equal responsibility for 
career development and discuss the importance of continually acquiring valued career capital.

The results show that knowledge workers need to take personal responsibility for managing their career but at the same time realise that organisations offer many opportunities for formal and informal development. Knowledge workers have to play the important role of influencing their workplace environment to make it conducive for further acquisition of career capital. They need to be open to continual training and development and applying the learning in creating innovative ways to getting their work done. They must actively seek out mentors and other networks within the organisation and focus on being known for delivery, self-motivation, perseverance and being adaptable to new methods of working. They also need to determine what career capital is the currency of the realm in their industry.

Academics need to carefully consider whether the concept of the boundaryless career has been overstated in the literature and to determine via empirical evidence what the level of mobility is of successful knowledge workers. The data in this study shows that mobility between companies and industries is not viewed as a successful career management device. Academics also need to refine the concept of social capital to emphasise that the most valued networks are within the organisation rather than in broader industry or society.

Further research in the following areas that would be of interest: to replicate this study internationally particularly in countries which score in the top 10 of the Global Competiveness Review in which the labour markets differ greatly to the emerging economies; To replicate this study with highly successful individuals and CEOs: to do a multivariate analysis simultaneously on; career success, the perceived importance of career capital components and the methods of their accrual.

\section{References}

Adler, P. S. and Kwon, S. 2002. 'Social capital: Prospects for a new concept', Academy of Management Review, 27: 17-40.

Arthur, M. 2008. 'Examining contemporary careers: A call for interdisciplinary inquiry', Human Relations, 61(2): 163-186.

Arthur, M. and Rousseau, D. 1996. The boundaryless career: A new employment principle for a new organisational era. New York, NY: Oxford University Press.

Banai, M. and Wes, H. 2004. 'Boundaryless global careers: The international itenerants', International Studies of Management and Organisation, 34(3): 96-130.

Ballout, H. 2007. 'Career success: The effects of human capital, person-environment fit and organisational support', Journal of Managerial Psychology, 22(8): 741-765.

Baugh, G. and Sullivan, S. 2005. 'Mentoring and career development', Career Development International, 10(6-7): 425426.
Baruch, Y. 2004. Managing careers: Theory and practice. Harlow: UK: Prenctice-Hall.

Baruch, Y. and Hall, D.T. 2004 'The academic career: A model for future careers in other sectors?', Journal of Vocational Behavior, 64(2): $241-262$

Baruch, Y. 2006. 'Career development in organisations and beyond: Balancing traditional and contemporary viewpoints', Human Resource Management Review, 16: 25-138.

Bourdieu, P. 1986. 'The forms of capital'. In Richardson, J.G. (ed). Handbook of theory and research for sociology of education. New York: Greenwood Press.

Boxall, P. 2007. The goals of HRM. The Oxford Handbook of Human Resources Management. Oxford: Oxford University Press.

Burfitt, A. and Ferrari, E. 2008. 'The housing and neighbourhood impacts of knowledge-based economic development following industrial closure', Policy Studies, 29(3): 293-304.

Burke, R.J. and Ng, E. 2006. 'The changing nature of work and organizations: Implications for human resource management', Human Resource Management Review, 16: 86-94

Cappellen, T. and Janssens, T. 2005. 'Career paths of global managers: Towards future research', Journal of World Business, 40: 348-360.

Chen, T., Chang, P. and Yeh, C. 2003. 'The study of career needs, career development programmes and job satisfaction levels of R\&D personnel: The case of Taiwan', The International Journal of Human Resource Management, 14(6): 1001 - 1026

Clarke, M. and Patrickson, M. 2008. 'The new covenant of employability', Employee Relations, 30(2): 121-141.

Clarke, M. 2013. 'The organizational career; not dead but in need of redefinition', The International Journal of Human Resource Management, 24(3-4): 684-703

DeFillippi, R. and Arthur, M. 1994. 'The boundaryless career: A competency-based perspective', Journal of Organisational Behaviour, 15(6): 307-324.

De Vos, A. and Dries, N. 2013. 'Applying a talent management lens to career management: The role of human capital composition and continuity', The International Journal of Human Resource Management. 24(9-10): 1816-1831.

Dickmann, M. and Harris, H. 2005. 'Developing career capital for global careers: The role of international assignments', Journal of World Business, 40(4): 399-408

Donnelly, R. 2009. 'Career behaviour in the knowledge economy: Experiences and perceptions of career mobility among management and IT consultants in the UK and the USA', Journal of Vocational Behaviour, 75: 319-328.

Edvinsson, 1 2002. 'The new knowledge economics', Business Strategy Review, 13(3): $72-76$. 
Forrier, A., Sels, L. and Steynen, D. 2009. 'Career mobility at the intersection between agent and structure: A conceptual model', Journal of Occupational and Organisational Psychology, 82: 739759.

Fugate, M. and Ashforth, B. 2003. 'Employability: The construct, its dimensions, and applications', Academy of Management Proceedings.

Fugate, M., Kinicki, A.J. and Ashforth, B.E. 2004. 'Employability: A psycho-social construct, its dimensions, and applications', Journal of Vocational Behaviour, 65: 14-38.

Hall, D., Gardner, W. and Baugh, S. 2008. The questions we ask about authenticity and attainability: How do values and beliefs influence our career decisions? Academy Of Management Confernec paper. Anaheim, CA.

Harris, R.G. 2001. 'The knowledge-based economy: Intellectual origins and new economic perspectives', International Journal of Management Reviews, 3(1): 21-40.

Haslberger, A. and Brewster, C. 2009. 'Capital gains: Expatriate adjustment and the psychological contract in international careers', Human Resources Management, 48(3): 379-397.

Heilmann, P. 2011. 'The dialectics between boundaryless career and competence development findings among Finnish ICT and paper managers', The International Journal of Human Resource Management, 22(1): 181-196

Herriot, P. 1998. Careers. (M. Poole, \& M. Warner, Eds.) The Handbook of Human Resource Management , 469-480.

Inkson, K. and Arthur, M. 2001. 'How to be a successful career capitalist', Organisational Dynamics, 30(1): 48-61.

Inkson, K. and King, Z. 2011. 'Contested terrain in careers: A psychological contract model', Human Relations 64(1): 35-57.

Jones, C. and DeFillippi, R.J. 1996. 'Back to the future in film: Combining industry and self-knowledge to meet the career challenges of the 21st Century', The Academy of Management Executive, 10(4): 89-103.

Kuijpers, M. and Scheerens, J. 2006. 'Career competencies for the modern career', Journal of Career Development, 32(4): 303-319.

Lamb, M. and Sutherland, M. 2010. 'The components of career capital for knowledge workers in the global economy', The International Journal of Human Resource Management, 21(1-3): 295-312.

Lazarova, M. and Taylor, S. 2009. 'Boundaryless careers, social capital, and knowledge management: Implications for organizational performance', Journal of Organizational Behavior, 30: $119-139$

Mallon, M. and Walton, S. 2005. 'Career and learning: The ins and the outs of it', Personnel Review, 34(4): 468-487

Martin, J.E. and Marshall, L.H. 1995. 'Choice maker: A comprehensive self-determination transition program', Intervention in school and clinic, 30: $147-156$.
Mayrhofer, W., Meyer, M., Iellatchitch, A. and Schiffinger, M. 2004. 'Careers and human resource management - a European perspective', Human Resource Management Review 14: 473-498.

McArdle, S., Waters, L., Briscoe, J.P. and Hall, D.T. 2007. 'Emplyability during unemployment: Adaptability, career identity and human and social capital', Journal of Vocational Behaviour, 71: 247-264.

Miles, M.B. and Huberman, A.M. 1994. Qualitative Data Analysis, 2nd Edition, California, SAGE Publications, Inc.

Mrinalini, N. and Nath, P. 2008. 'Knowledge management in research and technology organizations in a globalized era', Perspectives on Global Development \& Technology, 7(1): 37-54.

Parker, H. and Arthur, M. 2000. Careers, organising and community. Oxford: Oxford University Press.

Perotti, J.W., Wall, P. and McLaughlin, G. 2010. 'The future of knowledge work: Predictions for 2020', On the Horizon, 18 (3): 213-221.

Pringle, J. and Mallon, M. 2003. 'Challenges of the boundaryless odyssey', International Journal of Human Resources Management, 14(5): 839-853.

Sullivan, S. and Baruch, Y. 2009. 'Advances in career theory and research: A critical review and agenda for future exploration', Journal of Management, 35(6): 1542-1571.

Sutherland, M. and Jordaan, W. 2004. 'Factors affecting the retention of knowledge workers', South African Journal of Human Resource Management, 2(2): 63-72.

Suutari, V. and Makela, K. 2007. 'The career capital of managers with global careers', Journal of Managerial Psychology, 22(7): 628648 .

Suutari, V. and Smale, A. 2008. 'Designing IB curricula for future global careerists: A boundaryless career perspective', Journal of Teaching in International Business, 19(2): 167-191.

Tai, W. and Chen C. 2009. 'A new evaluation model for intellectual capital based on computing with linguistic variable', Expert Systems with Applications, 36(2): 3483-3488.

The Centre for International Labour Market Studies. 2011. Labour Market Intelligent Survey. Robert Gordon University.

Trevor, C. 2001. 'Interactions amongst ease-of-movement determinants and job satisfaction in the prediction of voluntary turnover', Academy of Management Journal, 44: 621-638.

Verbruggen, M., Sels, L. and Forrier, A. 2007. 'Unraveling the relationship between organisational career management and the need for external career councelling', Journal of Vocational Behaviour, 71: 69-83.

Zikmund, W. 2003. Business Research Methods. United States of America, South Western a division of Thomson Learning . 